\title{
Analysis of Palaeogene strike-slip tectonics along the southern East Greenland margin (Sødalen area)
}

\author{
Pierpaolo Guarnieri
}

This paper describes structural data collected during field work in southern East Greenland, a region characterised by a complex tectonic history. Here, 3D photogeology based on aerial and oblique photographs using high-resolution photogrammetry of a $150 \mathrm{~km}^{2}$ area in Sødalen in southern East Greenland shows ESE-WNW-trending faults cross-cutting Paleocene rift structures and flexure-related normal faults. The kinematic analysis highlights oblique and left-lateral strike-slip movements along faults oriented $120^{\circ}$. Strike-slip and dip-slip kinematic indicators on the walls of the chilled contacts between alkaline E-W-oriented dykes and the volcanic host rocks suggest that the faults and dykes formed at the same time, or maybe the faults were re-activated at a later stage. Palaeostress analysis, performed by inversion of fault-slip data, shows the presence of three different tectonic events. Coupling the 3D photogeological tool with structural analysis at key localities is a fundamental way to understand better the tectonic history of such a large area.

\section{Geological setting}

The Blosseville Kyst in southern East Greenland is characterised by a thick sequence of flood basalts and mafic intrusions (Fig. 1). The Skaergaard layered gabbro, the Miki Fjord macrodyke and dolerite sill complexes were formed during the continental break-up and the initial opening of the North-East Atlantic ocean at 55 Ma (Nielsen 1975; Karson \& Brooks 1999; Tegner et al. 2008).

In the Sødalen region pre-basaltic sediments characterise the Kangerlussuaq Basin and the lower part of the Blosseville Group (Wager 1947; Nielsen et al. 1981). Sedimentological studies recognise different facies associations of late Aptian to late Paleocene age (Larsen, M. et al. 1999). The youngest part of the basin comprises interfingering Paleocene volcanic units. Based on stratigraphy, geochemistry and petrography, the lavas of the Blosseville Group have been divided into two main series: (1) a $2 \mathrm{~km}$ thick sequence of volcanic rocks that formed in a continental rift environment (Nielsen et al. 1981), and (2) a 6 $\mathrm{km}$ thick sequence of plateau basalts (Larsen, L.M. et al. 1989). Furthermore, the Blosseville Kyst is characterised by different generations of dykes and sills, partly related to the break-up and post-break-up history (Wager 1947; Hanghøj et al. 2003).
Southern East Greenland is a type example of a volcanic rifted margin (Geoffroy 2005). The geological evolution of the margin is interpreted as the result of a NE-SW-oriented Late Cretaceous rifting phase that led to the onset of oceanic spreading in the Late Paleocene - Early Eocene (c. $55 \mathrm{Ma}$ ) after a period of syn-rift continental tectonism and volcanism. The general south-east dip of the basalts, the presence of landwarddipping normal faults and the coastal dyke swarm suggest a regional lithosphere flexure (Larsen, H.C. \& Saunders 1998).

\section{Sødalen region}

Sødalen is an $8 \mathrm{~km}$ long, NW-SE-oriented, U-shaped glacial valley extending SE-NW up to the 'Sødalengletscher' (Fig. $2 \mathrm{~A})$. The bedrock of the area is characterised by gneiss basement, locally overlain by syn-rift sedimentary and volcanic rocks that form a monocline that dips south-eastwards. The late Paleocene syn-rift sedimentary rocks crop out along the western side of the valley; they are unconformably overlain by sedimentary rocks belonging to the Vandfaldsdalen Forma-

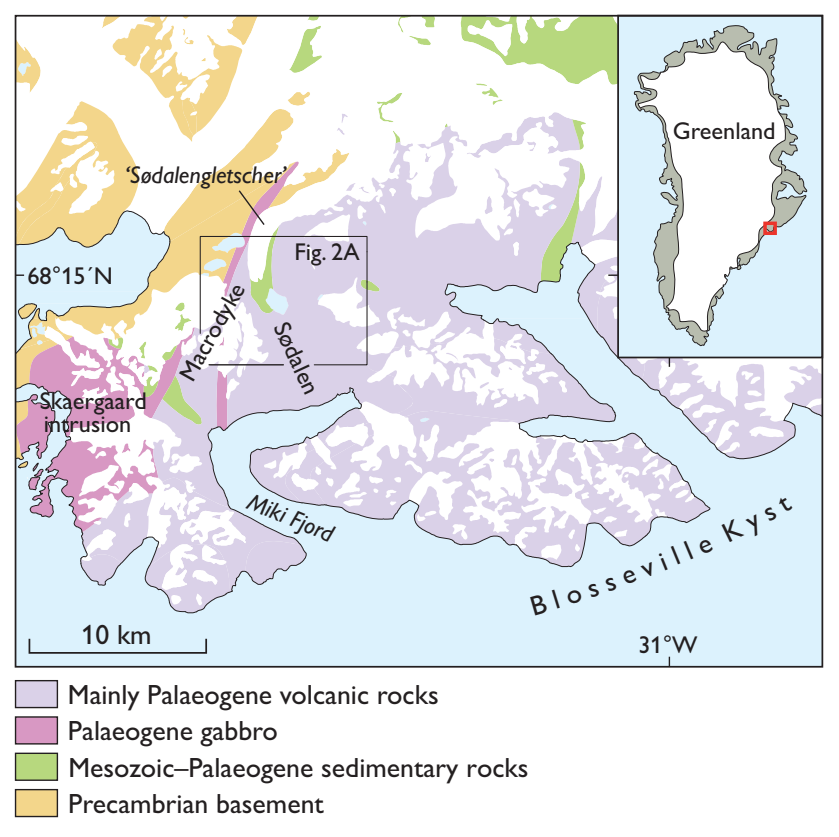

Fig. 1. Simplified geological map of the Sødalen region in southern East Greenland. 

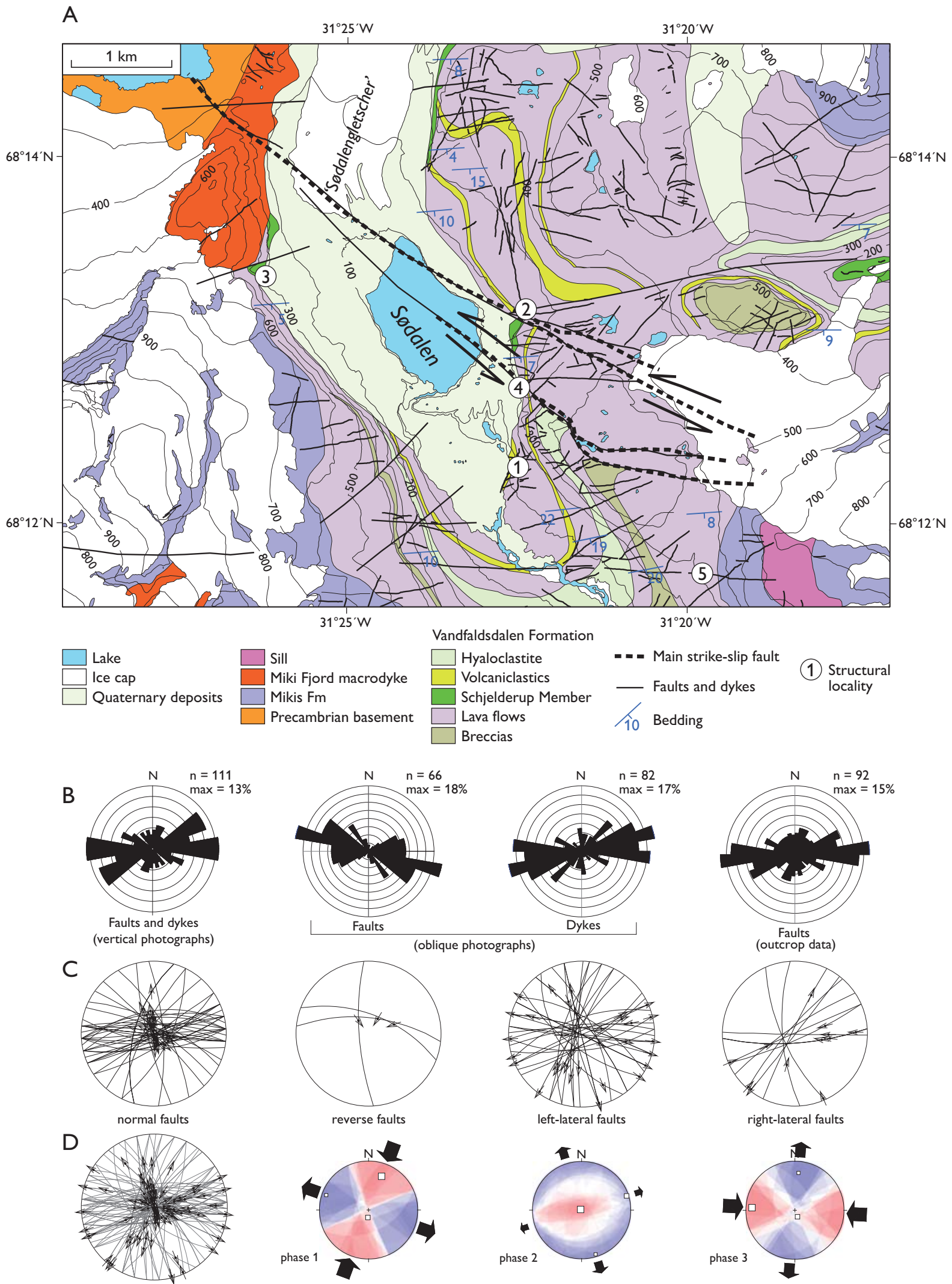

all faults $(n=92)$
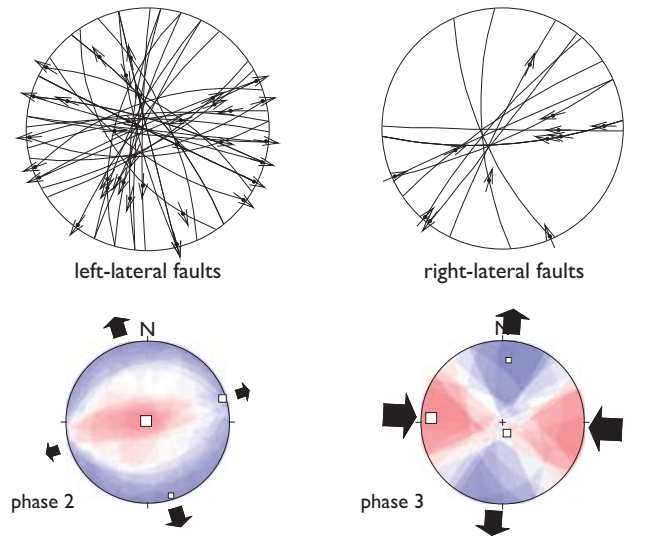

right-lateral faults

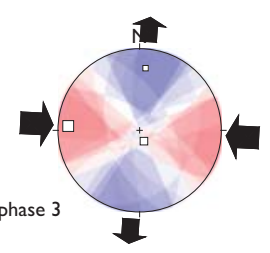

$\square S_{1}>\square S_{2}>\square S_{3}$ 
tion (Nielsen et al. 1981). The unconformity may be related to pre-volcanic uplift, coeval with the NE-SW-oriented rifting, followed by a rapid subsidence that accommodated the volcanism (Larsen, M. et al. 1999). The continental breakup is contemporaneous with the emplacement of layered gabbro bodies dated to $c .55 \mathrm{Ma}$, which formed at $c .2 \mathrm{~km}$ depth in the continental crust. The Skaergaard intrusion and the Miki Fjord macrodyke (Nielsen et al. 1981; Tegner et al. 2008) are contemporaneous with the up to $6 \mathrm{~km}$ thick sequence of plateau basalts (Larsen, L.M. et al. 1989).

\section{Structural data}

A total of 350 measurements for structural analysis were collected, from two sources: (1) from outcrops (metre scale) at five sites used for kinematic analysis and (2) from 3D photogeology to evaluate strike and dip direction and cross-cutting relationships of faults and dykes using vertical aerial photographs (kilometre scale) and oblique photographs $(100 \mathrm{~m}$ scale). A new tool for photogeology and mapping is developed and implemented at GEUS to collect geological features as 3D polylines with a descriptive GIS database suitable for 3D modelling (Vosgerau et al. 2010).

Dykes - Three main generations of dykes are found in the area. Their relative ages can be established from cross-cutting relationships, which show that the oldest generation $\left(D_{1}\right)$ is mainly NE-SW-oriented, orthogonal to bedding or landward-dipping; the trend is parallel to the Miki Fjord macrodyke. The average trend of the second generation $\left(D_{2}\right)$ is ENE-WSW and these dykes are almost vertical (Fig. 2B). The third generation of dykes found in the area $\left(\mathrm{D}_{3}\right)$ trends E-W (Fig. 2B).

Faults - Two main trends of fault traces, up to $2 \mathrm{~km}$ long, can be followed on the vertical aerial photographs (Fig. 2B). The oldest generation $\left(\mathrm{F}_{1}\right)$ is characterised by ENE-WSWoriented normal faults. These faults are mainly landward-

\footnotetext{
Facing page:

Fig. 2. Structural data analysis. A: Geological map of the Sødalen area (modified from Nielsen et al. 1981). Arrows show the direction of movement along strike-slip faults; contour lines $100 \mathrm{~m}$. B: Rose diagrams for orientation of faults and dykes. C: Lower hemisphere stereographic projection of faults grouped by kinematics; arrows show the slip vector. $\mathbf{D}$ : Palaeostress analysis of 92 fault-slip measurements. Black arrows indicate maximum horizontal shortening/extension; $\sigma 1, \sigma 2, \sigma 3$ = principal axes of stress. Visualisation of the right dihedral method $(\mathrm{red}=$ pressure, blue $=$ tension) shows planes that are likely to have been re-activated (the three diagrams to the right).
}

dipping and are interpreted as flexure-related faults (Wager 1947; Nielsen et al. 1981). At site 3 (Fig. 2A), the Miki Fjord macrodyke contact is downfaulted by a landward-dipping $\left(F_{1}\right)$ normal fault with an average vertical offset of $400 \mathrm{~m}$. The youngest $\left(\mathrm{F}_{2}\right)$ faults trend ESE-WNW. South-east of localities 2 and 4 (Fig. 2A), the fault traces are curved in planar view typical of strike-slip fault systems.

\section{Kinematic analysis}

Field data suitable for fault-slip analysis include measurements of fault plane orientations, slip directions, senses of slip and bedding orientations. The slip direction of faults is determined using slickensides and calcite fibres on the fault plane. Sense of slip indicators include tails and scratches and crescentic marks formed by intersection of the fault plane with secondary fractures such as: R, R', P and T (Petit 1987).

Data collected in the canyon at locality 2 (Fig. 2A) define the kinematics of a $120^{\circ}$-trending fault corresponding to a major left-lateral strike-slip fault that cuts the basalts. The fault zone is $c .50 \mathrm{~m}$ wide and contains a $>50 \mathrm{~cm}$ thick calcite vein. Double movement along the fault plane with welldeveloped dip-slip and strike-slip slickensides and calcite fibres suggests a reactivation of the fault (Fig. 3). The estimated vertical offset, based on the tectonic contact between two stratigraphic markers, is around $250 \mathrm{~m}$, whereas the horizontal offset is estimated to $500 \mathrm{~m}$. This results in a more than 50-150 m wide, $120^{\circ}$-trending, rhomb-shaped fault zone, $1 \mathrm{~km}$ long in map view (Fig. 2A, locality 2) and with a negative flower structure in cross-section. To the south-east, the fault trace disappears below an ice cap and to the north-west it is covered by the moraine in front of 'Sødalengletscher', but it is exposed on the western side of Sødalen, where a well-

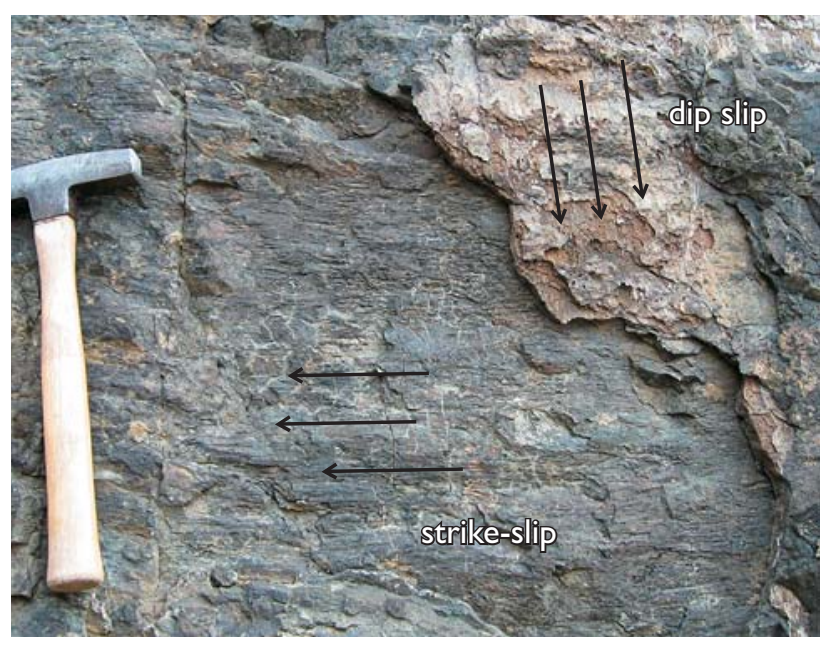

Fig. 3. Evidence of multiple re-activation of a fault testified by well-developed dip-slip and strike-slip slickensides on a fault plane (locality 2 in Fig. 2A). 
developed vertical cleavage, locally with strike-slip slickensides, cross-cuts the Miki Fjord macrodyke.

At locality 5 (Fig. 2A), a 4 km long E-W-oriented dyke crosses Sødalen; it is an example of the latest dyke generation $\left(D_{3}\right)$. Slickensides are found on the chilled margins of the dyke, which show that both dip-slip and strike-slip movements have taken place. The trend of the dykes, coupled with evidence of multiple reactivation of the contact, suggests a relationship between strike-slip faults and dykes in which normal faults intruded by dykes were re-activated as leftlateral faults in a NNE-SSW extensional regime associated with the ESE-WNW-trending shear-zone (Fig. 2A).

\section{Palaeostress analysis}

Palaeostress analysis of the heterogeneous fault-slip data set was performed using integrated software for structural analysis (Žalohar 2009). More than 90 fault-slip measurements were taken at five sites (localities 2A-C) and used for inversion to obtain palaeostress values. The Gauss Method associated with visualisation of P\&T dihedra (Žalohar 2009) distinguishes three superimposed tectonic phases in the area (Fig. 2D): (1) a phase with strike-slip regime and a $20-30^{\circ}$ trending maximum horizontal shortening interpreted as oblique rifting; (2) a phase with a SSE-NNW-trending maximum horizontal extension that corresponds to the coastal flexure and (3) a phase with strike-slip regime and a $95^{\circ}$-trending maximum horizontal shortening that caused the inversion and uplift of the entire area.

\section{Conclusions}

The structural data collected in Sødalen indicate the presence of strike-slip faults related to two tectonic events separated in time by the coastal flexure. The youngest structures and dykes (phase 3; Fig. 2D) are associated with a NW-SE left-lateral shear zone that cross-cuts the Paleocene rift and the structures related to the coastal flexure of the continental margin (phase 2). The evidence of dyke intrusions related to $\mathrm{N}-\mathrm{S}$ extension compatible with the strike-slip tectonic regime of phase 3 , suggests a coexistence of the two phenomena as a superficial expression of deep-seated crustal structures. The oldest structures and dykes of phase 1 show a maximum horizontal extension coherent with the trend of the Miki Fjord macrodyke. This strike-slip tectonic regime could be related to an oblique rifting stage in Paleocene time. Finally, the accuracy of the 3D photogeological tool is tested over a range of kilometre to metre scale (Fig. $2 \mathrm{~B}$ ) showing the power of this method developed at the Survey.

\section{Acknowledgement}

Chevron is thanked for interest and financial support.

\section{References}

Geoffroy, L.: 2005. Volcanic passive margins. Comptes Rendus Geoscience 337, 1395-1408.

Hanghøj K., Storey M. \& Stecher O. 2003: An isotope and trace element study of the East Greenland Tertiary dyke swarm: constraints on temporal and spatial evolution during continental rifting. Journal of Petrology 44, 2081-2112.

Karson, J.A. \& Brooks, C.K. 1999: Structural and magmatic segmentation of the Tertiary East Greenland volcanic rifted margin. In: Ryan, P.D. (ed.): Continental tectonics. Geological Society Special Publications (London) 164, 313-338.

Larsen, H.C. \& Saunders A.D. 1998: Tectonism and volcanism at the southeast Greenland rifted margin: a record of plume impact and later continental rupture. Proceedings of the Ocean Drilling Program, Scientific Results 152, 503-534.

Larsen, L.M., Watt, W.S. \& Watt, M. 1989: Geology and petrology of the Lower Tertiary plateau basalts of the Scoresby Sund region, East Greenland. Bulletin Grønlands Geologiske Undersøgelse 157, 164 pp.

Larsen, M., Hamberg, L., Olaussen, S., Nørgaard-Pedersen, N. \& Stemmerik, L. 1999: Basin evolution in southern East Greenland: an outcrop analog for Cretaceous-Paleogene basins on the North Atlantic volcanic margins. AAPG Bulletin 83, 1236-1261.

Nielsen,T.F.D. 1975: Possible mechanism of continental breakup in the North Atlantic. Nature 253, 182-184.

Nielsen, T.F.D., Soper, N.J., Brooks, C.K., Faller, A.M., Higgins, A.C. \& Matthews, D.W. 1981: The pre-basaltic sediments and the Lower Basalts at Kangerdlugssuaq, East Greenland: their stratigraphy, lithology, palaeomagnetism and petrology. Meddelelser om Grønland Geoscience 6, 3-25.

Petit, J.P. 1987: Criteria for the sense of movement on fault surfaces in brittle rocks. Journal of Structural Geology 9, 597-608.

Tegner, C., Brooks, C.K., Duncan, R.A., Heister, L.E. \& Bernstein, S. 2008: ${ }^{40} \mathrm{Ar}^{-39} \mathrm{Ar}$ ages of intrusions in East Greenland: rift-to-drift transition over the Iceland hotspot. Lithos 101, 480-500.

Vosgerau H., Guarnieri P., Weibel R., Larsen M., Dennehy, C., Sørensen, E.V. \& Knudsen, C. 2010: Study of a Palaeogene intrabasaltic sedimentary unit in southern East Greenland: from 3-D photogeology to micropetrography. Geological Survey of Denmark and Greenland Bulletin 20, 75-78.

Wager, L.R. 1947: Geological investigations in East Greenland, Part IV: The stratigraphy and tectonics of Knud Rasmussens Land and the Kangerdlugssuaq region. Meddelelser om Grønland 134(5), 62 pp.

Žalohar, J. 2009: T-TECTO 3.0 Professional. Integrated software for structural analysis of fault-slip data. Department of Geology, SI-1000 Ljubljana, Slovenia. 